\title{
Article \\ Differentiation of Rights in the Norwegian Welfare State: Hierarchies of Belonging and Humanitarian Exceptionalism
}

\author{
Synnøve Bendixsen \\ Department of Social Anthropology, University of Bergen, 5020 Bergen, Norway; E-Mail: synnove.bendixsen@uib.no
}

Submitted: 3 April 2018 | Accepted: 15 May 2018 | Published: 30 August 2018

\begin{abstract}
Controlling mobility and borders has become a central, defining feature of the state today. Using the Norwegian welfare state as a case study, I argue that the differentiation of rights depending on status categories is an important way in which the state deals with irregular migration. It is also an integral element of border construction and how mobility is managed. How is the Norwegian welfare state differentiating the rights to work, health care, and economic welfare benefits and through which argumentations does the state legitimate these differentiations? This article argues that the practice of differentiation contributes to establishing hierarchies of belonging and enforces the nexus of welfare rights-migration management. Further, the exclusion of certain categories of people from accessing basic welfare services and, consequently, creating precarious lives, is legitimized by the discourse of humanitarian exceptionalism, through which migrants gain some support outside the welfare state system. This facilitates policies and regulations that are "tough on migration", and produces the irregular subject as apolitical, a victim, and unwanted. The differentiation of rights and the discourses that the state uses to legitimate these differentiations are keys in the negotiation of who should be entitled to which rights in the future.
\end{abstract}

\section{Keywords}

asylum; borders; differentiated rights; health care rights; humanitarian exceptionalism; irregular migrants; Norway; welfare state

\section{Issue}

This article is part of the issue "Migration, Boundaries and Differentiated Citizenship", edited by Terry Wotherspoon (University of Saskatchewan, Canada).

(C) 2018 by the author; licensee Cogitatio (Lisbon, Portugal). This article is licensed under a Creative Commons Attribution 4.0 International License (CC BY).

\section{Introduction}

In the spectacle of borders, citizenship and its subsequent rights play a key part in how and where borders materialize. The politics of citizenship as institutionalised in immigration law and elsewhere create unequal access to rights and shapes differentiated forms of belonging. It also produces statuses that are precarious and subject positions that are characterised by "illegality" and deportability. The state legitimizes its sovereign and disciplinary power based on its claim over a territory and that it serves a representable population, the citizenrya population that must be continuously produced, which is one of the most fundamental tasks of the state. The existence of irregular migrants-i.e., migrants without a legal permit to stay in the country-is considered as a sign of the lack of control over the territory, a security problem and as contributing to the undermining of the welfare state. In Norway, there are around 18,000 irregular migrants-mostly rejected asylum seekers who have not returned to their country of origin (Oslo Economics, 2014). Increasingly, how to deal with irregular migrants is high on the political agenda in Norway as in other European nation-states. This article examines the differentiation of welfare rights as part of how the Norwegian state deals with irregular migrants in particular and migration management in general, and how this transforms the welfare state.

The literature on asylum seekers in Europe has taken notice to the proliferation of borders (e.g., Balibar, 2002; Mezzadra \& Neilson, 2013; Rumford, 2010). Borders are no longer, if they ever were, geographical markers of 
state territories, but rather come into existence in various social spaces (Balibar, 2002). Contemporary borders are multifaceted social institutions composed through relationships constituted by the law, the market, and social relations (Mezzadra \& Neilson, 2013; Vuolajärvi, 2018). Scholars have suggested that policies for managing migration have been shifted up, out and down (Guiraudon \& Lahav, 2000), involving actors such as EU bodies (Europol and Frontex), private parties such as airlines, and local government and service providers (Lavenex, 2006).

The multiplicity of borders-e-borders, offshore borders, juxtaposed borders, smart borders (Rumford, 2010)- has been linked to how the border has become a spectacle (de Genova, 2002) due to the politicization and securitization of migration (Bigo, 2002). De Genova (2002) has shown how deportability has become an important feature of how nation-states control migrants: irregular migrants face the possibility of coercive expulsion from the space of the state, making them live in permanent fear and vulnerability.

In this article, I explore how welfare rights are used as an important technique of control and management of irregular migration. I will examine the construction of three rights, namely the right to work, the right to health care, and economic welfare benefits. While the two latter are related to welfare benefits, the right to work is indirectly linked insofar that the Norwegian constitution $\S 110$ declares that if one cannot "support oneself" one has the right to support from the public (Kongeriket Norges, 2018, § 110). These are fields of rights that represent important constituents, as will be discussed, in the production of who should belong and be included in the Norway welfare state. The differentiation of these rights, I argue, are important boundary-producing and normality-constructing discourses that are instrumental in establishing over which citizen-subjects the state can claim to realize its sovereignty and right to rule. The production of such differentiated rights is part of the statecraft that produces a particular image of the citizen who should be supported by the welfare state and the "illegal" non-citizen who should be cast away. My discussion draws on public documents, parliamentary reports, regulations, the media, and public statements. Due to the complexity of these developments, the description will be a general overview.

I first lay out the mechanisms by which the modern welfare state creates a type of inclusion/exclusion dynamic and then turn to the Norwegian welfare state as my case study. In this part, I explore the policies concerning health care for irregular migrants, followed by an investigation of how the right to work has been regulated for refugees and a discussion of how changes in economic benefits of irregular migrants have played out. I then briefly discuss the parallel voluntary health care offered to irregular migrants. Before I offer a conclusion, in the final part I discuss how these rights and their representations are part of (re)defining, (re)producing, and (re)constituting migration management and people production in contemporary Norway by investigating aspects of belonging and humanitarian exceptionalism.

\section{The Welfare State's People Production as an Analytical Framework}

In order for the modern state to be considered as a practical and effective institution, there must be a community of citizen-subjects that both anchor and are represented by it. How to carve out, stabilize, and operationalize a particular citizen figure that the modern state can represent is a foundational assignment of the state (Soguk, 1999, p. 39). This is the "people production" of the state (Appadurai, 1996, p. 43)-an essential task for legitimizing the state's power and a task that it must continually perform. Here, I follow Abrams's (1988) call for studying the state not as a singular abstract-formal entity, but as an idea, an ideological project, as well as consisting of "real power" such as immigration departments, prisons, and deportation orders. The state comes into being through: 1) ideas of the state that are produced and converted under particular historical conditions, and 2) political and public practices that are carried out in the name of the state (Abrams, 1988). Rather than considering the state as a coordinated strategic entity, this view of the state recognizes the coexistence of contradictory, divergent and overlapping processes, discourses, and practices.

The welfare state has played an important role in states' success in generating particular kinds of subjects and identities (Roseberry, 1994). One consequence of the development of the welfare state was that the borders shifted from being geographical-at the physical border of the nation-state-to being structural borders: in order to be included at various levels, the subject had to be in "the system" (Bommes \& Thränhardt, 2010). Most welfare states have established "thresholds of inequality" (Bommes \& Thränhardt, 2010), contributing to the constitution of nations as entities with power to provide or deny political and social rights, determine access to social welfare for specific social groups and generating a naturalized understanding of the world by its production of social normativity and practices (Skey, 2013). The internal loyalty of citizens is guaranteed through a welfare policy that promotes possibilities for inclusion for some that are based on external closure and exclusion of others from the welfare state.

The welfare provided by the nation-state was territorially marked: the political form of membership, i.e., citizenship, constructed a people considered as belonging to the state territory, the primary addressee of the welfare state provision, and an idea of substantial equality for all members of this national community (Bommes \& Thränhardt, 2010). While the nation was defined in various ways (e.g., through culture in Germany and in republican terms in France), the common welfare of the people-the community of national citizens-came to be the wide-ranging frame of reference (Bommes, 1999). 
In this construction of the state, citizens and the insider alien without citizenship (the Other) are mutually constitutive: an insider identity is made possible by a parallel marking of the outsider (Isin, 2002). The insider/outsider dynamic is a continuous feature of all political communities, although modified in time and space as the form and character of the polity changes. Yet, the citizen/non-citizen division should not be thought of as overly dichotomous (Anderson, 2013). Instead, there is a sliding transition between the categories in terms of rights, precariousness and mechanisms of inclusion/exclusion. Non-citizens are categorized into various subgroups, such as "illegal" migrants, Au Pairs, and European Union/European Economic Association (EU/EEA) nationals, depending on the legal status they are granted by the state. Notably, while EU citizens have more rights than "third-country nationals" (non-European citizens), they can also be considered irregular migrants if they do not fully comply with regulation of the rights to residence (Caudra \& Staaf, 2014). Rather than thinking about citizenship as the door-opener to all rights in the state and the end of precariousness, Anderson (2013) urges us to recognize and reconsider the continuous forms of differentiations pursued within the citizenship category. These differentiations are produced by the construction of certain categories and immigration statuses, which create specific forms of exclusion and incorporation.

\section{Differentiated Rights to Work, Health and Economic Benefit}

The way the Norwegian state deals with irregular migrants must be understood from the concept of the "nation" as tied up to its particular welfare state model. ${ }^{1}$ Social services are considered a public responsibility, which emphasize equal rights for all citizens, financed through taxation. The right to welfare is based on residence and legal status (as a permanent or temporary resident), rather than employment, income, or previous contributions to the welfare system. While the social democratic welfare state historically had a meanstested insurance scheme, since the 1960s, different kinds of arguments were made in favor of universal (general, adequate) welfare schemes. After the Second World War, the concept of "unworthy" people lost ground, simultaneously as the concept of human rights and the idea that all citizens are "equal" were introduced. Together with dignity arguments (self-respect and equality), economic and bureaucratic efficiency arguments were part of promoting the principle of universal social programs (Kildal \& Kuhnle, 2005). Additionally, the social democratic parties made the universal welfare state part of their image and trademark, promoting it as endorsing egalitarianism, fighting social differentiation, and encouraging solidarity across class compared to selective, means-testing, and stigmatizing programs which the middle classes and well-off would presumably be more reluctant paying taxes to maintain. Since the 1990s, modifications in the Norwegian welfare policy developments have been implemented, representing a move towards selectivism, targeting, and a norm of reciprocity (Kildal \& Kuhnle, 2005). For example, a new work approach has strengthened the link between contribution and benefits, both practically and morally. There is also increased use of private providers of social and health services.

In European welfare policy reforms, general trends have been towards active instead of passive measures, negative sanctions, duties instead of rights, and selectivity instead of universal social rights (Kildal \& Kuhnle, 2005). Still, the Norwegian version of the universal welfare state remains socially constructed and institutionalized as an egalitarian sociocultural order (Bendixsen, Bringslid, \& Vike, 2018): it is partly built on the cultural construction of homogeneity (Jöhncke, 2007) and perceptions of equality. The ambition to integrate immigrants has largely involved resorting to traditional welfare state arrangements, and particularly labor market policies. The welfare state in Norway is part of the branding of the nation-state, a component of national identity (Vike, 2004), and is supposedly expressing and underpinning solidarity, equality, universality, and market independence, or decommodification (Cox, 2004). The national identity of the Norwegian state includes both that of the "universal welfare state", and, since the mid-1990s, that of being a "humanitarian superpower" through its engagement as mediator and facilitator in various conflicts around the world (Fuglerud, 2005). The Norwegian welfare state constitutes an emotional and moral community (Vike, 2004): the welfare state should provide care to groups, alleviate suffering, and make sure that no one lives under so-called undignified conditions. These values have become references to which policymakers must justify their proposals for reforms (Cox, 2004). Yet, this ambitious and almost unlimited way of taking responsibility for citizens' requirements has been challenged over the last few years as the former simplified perceived correlation between citizens and the nation-state's territory has been challenged.

\subsection{Asylum Seekers: The Right to Work}

Asylum seekers had the right to work while awaiting an answer to their application until the policy was changed in 2009. The condition for obtaining a work permit had been that there was no "doubt about the subject's identity", yet the applicant was not required to submit a passport or national identity card. This changed January 2009, when the Norwegian government set up new documentation requirements. Asylum seekers had to document their identity with a valid travel document in order to be granted the right to work.

\footnotetext{
${ }^{1}$ At the EU level, there are ongoing processes of harmonization policies and development of common standards in terms of chances for recognition and treatment of asylum seekers, including reception conditions across the EU, and in terms of rights that are granted to various categories of people.
} 
In Parliamentary Report 9 (2009-2010), the scheme is referred to as follows: "The reason for the change is the goal of making it less attractive for asylum seekers without protection needs to come to Norway primarily for the purpose of working". With the tightening of ID requirements, the government sought to stimulate asylum seekers into helping to clarify their identity: "as of today, only about $5 \%$ of applicants document their identity with a valid travel document when applying for asylum with the police" (Justis- og politidepartementet, 2010, Section 3.4.2). It was also meant to prevent asylum seekers whose identity was not formally confirmed from participating in society, which the permission to work during the application period would entail. Increased knowledge of asylum seekers' identities should also facilitate return and deportation. The government's aim was for Norway to become a less appealing destination for asylum seekers 'without protection needs' and for those who came from third countries to Norway to work (Valenta \& Thorshaug, 2011).

A report that evaluated the consequences of these tightened requirements argued that one of the consequences was that significantly fewer asylum seekers were granted temporary work permits (Valenta \& Thorshaug, 2011). Yet, the new prerequisites did not lead to more asylum seekers documenting their identity or obtaining identity documents (Valenta \& Thorshaug, 2011). Instead, asylum seekers' decisions concerning the obtaining of documents were shaped by factors such as the possibility of acquiring the necessary documents and their assessments of how that documentation would affect their asylum application process. These evaluations taken by the asylum seekers appear as more relevant than the possibility of potentially obtaining the right to work while waiting for the answer to their asylum applications. Simultaneously, this is not necessarily a rational decision left to the asylum seeker to take: for some asylum seekers, the documents are difficult or impossible to obtain. Further, in contrast to the government's aim that the tightening-up of documentation requirements would make Norway a less attractive country in which to seek asylum, the variations in asylum seeker arrivals were hardly or not at all affected by these changes (Valenta \& Thorshaug, 2011). Explanations for this are manifold. One is that the government overestimated the detailed information flow concerning the various nationstates' regulations and policies. Asylum seekers arriving in Norway may be unaware of the new requirements beforehand. Additionally, the government underestimated the degree to which asylum seekers arrive in the country where they seek asylum due to a number of reasons, including their social network, par hazard, family, social contacts, and economic abilities that are not linked to finding immediate employment. Those fleeing insecurity and violence appear to be less guided by the short-term (im)possibility to work and more by the longer-term possibility of achieving security and socio-economic integration in their country of asylum application.
Since there were no more asylum seekers who submitted their travel documents due to the changed regulations (Valenta \& Thorshaug, 2011), the measures did not facilitate return and deportation for the government. Yet, it enforced the production of the asylum seeker as a potentially deportable subject in the (near) future. Further, the document requirements made the wish to be economically and socially included through work into a right only available to some selected groups. While work is presented as a "duty" for those who are "on the dole" in the welfare state, work becomes a "right" for others whose intentions are not to be trusted.

\subsection{Irregular Migrants: The Right to Health Care}

From the moment they apply for asylum, asylum seekers and their family members have full rights to health care (Søvig, 2011). Children under the age of 18 have full rights to health and care services regardless of their residence status. Section 3-1 of the Health and Care Services Act (2011) states that municipalities must provide the necessary health services to all residents in the municipality.

For irregular migrants, the right to health care is more complex. In 2010, the government started a process of clarifying the legal situation of irregular migrants, but liberalization was not the intention. Today, people without a legal permit to stay have the right to "emergency health care" -health care that cannot be put on hold. They do not have the right to "necessary health care" given by the specialized branch of the health services. An exception is made for children (under the age of 18) in administrative practice, and this is done by the authorities with reference to the Convention of the Rights of the Child and the Committees' practice (Søvig, 2011). All pregnant women living in the country are entitled to necessary health care before and after childbirth, including maternity care. However, since they are not members of the National Insurance (folketrygden), they run the risk of paying for the health services themselves. Irregular migrants have the best legal position under the Act on Infectious Diseases (1994). While this right may be important for irregular migrants, it is based on the rationale of public health concerning the population more than concern for irregular migrants' medical conditions (Bendixsen, 2018).

In the government's clarification of the right to health care for people without legal permission to stay in the country, the starting point of accessing the right to health care should be that the patient should use the health services in his or her own country (Langset, 2011). It also specified that social and health caseworkers should make individual assessments on when the migrant "in practice" was going to or could leave the country before making a decision on health care provisions. This requires that the caseworker has knowledge about immigration policies and practices, such as return agreements and forced return (Karlsen, 2015). It exemplifies 
how case assessments have become connected to migration control.

\subsection{Economic Welfare Benefits}

The welfare state system has been opened up for the increased use of differentiation based on legal status not only when it comes to health care, but also when it comes to economic benefits. Currently, irregular migrants are allowed to stay in regular reception centers. Yet, the financial support a person would receive in the center is regulated according to the person's legal status. While the economic benefits for both asylum seekers and irregular migrants have been reduced since 2012 (see Table 1), the economic benefit for those with the right to receive social benefits from the state has increased in the same period, from 5,373 NOK in 2012, to 6,050 NOK in 2018 (Utlendingsdirektoratet, 2018). Reception centers can diminish the amount of money residents receive if they break house rules, such as not participating in activities presented as obligatory (Kjærre, 2015).

The rates for asylum seekers have always been well below social assistance rates and a slight growth up to 2015 was reversed so that the benefits in 2018 are lower than the rates were in 2011 . The government decided to reduce the economic benefit for those living in the reception center by $20 \%$ in 2016 in comparison to the 2015 rates. These changes can be understood in light of the idea of a "refugee crisis" in 2015 (Seeberg, 2017). Even though the number of asylum seekers arriving in Norway was lower than in several other countries, including Sweden and Germany, the "crisis" discourse contributed to a political approach that the government called the "necessary tightening in the asylum politic" in an agreement across political fractions on measures to meet the "refugee crisis" in November 2015 (Prime Minister's Office \& Ministry of Justice and Emergency Affairs, 2016, author's translation). In the UDI, the Norwegian Directorate of Immigration (Utlendingsdirektoratet), 2016 allocation letter (Justis-og beredskapsdepartementet, 2016) concerning reception centers, two new aspects were included: 1 ) the aim of developing a way to replace cash benefits with benefits, such as cash cards without the possibility of withdrawal, and 2) that residents in reception centers should not receive benefits at a level that makes Norway more attractive than other counties. In consequence, the UDI will ensure that the level of benefits and its arrangements for residents in reception centers of relevant European countries are made available in Norway. They will also pay attention to changes in benefits that these countries make. The arguments for implementing cards instead of cash were that it would prevent asylum seekers from being pressed to give the benefits they receive to pay debts to human traffickers and should prevent unaccompanied minors from being forced to send money to their families. According to the government, this would reduce the incentives families have for sending their children on the dangerous journey to Europe.

Introducing the idea that residents in asylum reception would no longer receive cash benefits can be seen as a strong indication that residents in asylum reception are not considered to be part of Norwegian society proper, despite the fact that many people either have received or will receive a residence permit and live in the country. It is also worth mentioning that in 2016 the living conditions of the population in reception centers were for the first time not compared to the living conditions of the rest of the population in Norway, but instead with the conditions for asylum seekers in other European countries, and sometimes with the living conditions for different groups in their countries of origin (Seeberg, 2017). One may ask whether it has become easier to keep asylum seekers completely outside the social and symbolic boundaries of Norwegian society.

\subsection{Responses to Differentiations of Rights: Parallel Care}

The variation in having certain rights makes it the duty of street-level bureaucrats, i.e., caseworkers at the Norwegian Labor and Welfare Administration (NAV), to know the specific status of the person in front of her/him who seeks to solicit health care rights. This can in some instances lead to the person's health needs, necessities, or requirements being put on hold. The caseworker should thus not focus on providing for the need that the person might have, but rather on whether the person meets

Table 1. Economic benefit rates, in NOK (2011-2018).

\begin{tabular}{llll}
\hline & $\begin{array}{l}\text { Rejected asylum seekers (irregular migrants) } \\
\text { living in reception center without meals }\end{array}$ & $\begin{array}{l}\text { Asylum seekers living in reception } \\
\text { center without meals }\end{array}$ & $\begin{array}{l}\text { State guidelines for social } \\
\text { benefits (single) }\end{array}$ \\
\hline 2011 & 1,910 & 3,158 & 5,288 \\
2012 & 1,960 & 3,220 & 5,373 \\
2013 & 1,960 & 3,260 & 5,500 \\
2014 & 1,980 & 2,920 & 5,600 \\
2015 & 1,980 & 2,920 & 5,700 \\
2016 & 1,780 & 2,340 & 5,850 \\
2017 & 1,830 & 2,404 & 5,950 \\
2018 & 1,861 & 2,447 & 6,050 \\
\hline
\end{tabular}


the state categorization of who should prosper within the nation-state constellation. This is nothing new per se: street level bureaucrats have had a gate-keeper role in distinguishing between the deserving and undeserving citizen for a long time. In the case of irregular migrants, this role adds another dimension as it takes on a bordering function. Additionally, welfare state policies towards irregular migrants are typically made through administrative decrees (regulations and circulars issued by directors, state departments, and instructors). This means that they are easily changed, which contributes to the general uncertainty and unpredictability in irregular migrants' lives (Karlsen, 2015). It also establishes a form of temporariness.

One consequence of the differentiation of rights and thus the limited right to health care for irregular migrants is the introduction of a parallel health care structure in Norway. I deal specifically with the construction of the parallel health care center here because it suggests how health care rights have become linked to discourses of humanitarian exceptionalism, compassion, and care. The health care center for paperless in Oslo, set up in 2010, along with a smaller one in Bergen, set up in 2014, offer free health care to irregular migrants. Those working there are professional volunteers (i.e., doctors, nurses, psychologists, laboratorians), who were frustrated that they cannot provide medical service to everyone through the public health care service in their everyday working life. Indeed, the ethics of welfare professionals on human values are at odds with the rationality of territorial sovereignty. The health care centers collaborate with the diaconal hospitals, facilitating some access for some irregular migrants. One response to this initiative came from the right-wing Progress Party (FrP) leader Siv Jensen:

Several non-profit organizations like the City Church Mission and the Red Cross are today offering help to illegal migrants in Norway who become sick. We understand the humanitarian and human assessments behind such help. But they are actually not allowed to live here, and the organizations contribute in prolonging their illegal stay. (NTB, 2010)

The number of organizations that provide clothes and food handouts expanded from the late-2000s onwards. Some of these were directed towards poor people in general: a large majority of these services were primarily oriented towards people with alcohol and drug problems, women in prostitution (Karlsen, 2015; Nuland, 2007), and "Roma-beggars". Again, such parallel institutions are nothing new; voluntary organizations have initiated activities, such as shelters for battered women before becoming an obligatory municipal task, often run by the municipalities themselves (Sivesind, Lorentzen, Selle, \& Wollebæk, 2002).

Yet, these parallel structures are structured and tolerated as humanitarian responses (Ticktin, 2006) towards people in need. Compassion and exceptional care be- come the core value in the approach towards asylum seekers and irregular migrants. The production of irregular migrants as not entitled to health care, but still provided for through humanitarian discourse, illustrates the effort of the nation-state to mark people as belonging to certain categories who should leave the territory. Differentiations of health care are also enabled by the existence of these parallel systems - the state accepts that these people should not be left to die, yet none of the state actors facilitate their continued lives (see, Agamben, 1998). In consequence, the message that irregular migrants are unwanted remains unambiguous.

\section{Discussion}

Restricting the possibility of obtaining a work permit, limiting health care rights and differentiating economic benefits underscore efforts by the welfare state to distinguish between a population for whom the welfare state is set up to provide service and the population that it seeks to get rid of. Restraining irregular migrants' access to public services is a frequent practice in several countries with broad welfare systems (van der Leun, 2006). What are the effects of this differentiated population management in the Norwegian case? Here, I will discuss three aspects: hierarchy of belonging, humanitarian exceptionalism, and enforcing the nexus of welfare rightsmigration management.

First, the differentiation of rights produced by the welfare state contributes to generating hierarchies of belonging and inclusion. Borders become constituted not as material institutions that separate the alien from the citizen, but as tied up to a different set of rights. This differentiation multiplies and brings material and non-material consequences to the different legal positions that non-citizens occupy, such as asylum seekers, refugees, irregular migrants, EU migrants, students, victims of trafficking, or family members. Differentiating rights is presented as the moral order of welfare society and as a naturalized part of the state's people production.

While the regulation of access to rights is a fundamental way of differentiation that structures people's conditions, representation has become vital in the negotiation of who should be entitled to certain rights in the future (Papadopoulos \& Tsianos, 2013). In dealing with migrants, the state has turned the neoliberal construction of employment in which work is the duty of all citizens into a privilege only accessible to citizens (Chauvin \& Garcés-Mascareñas, 2014). In Norway, the changed regulations contribute to limiting the public space available for asylum seekers to be viewed as a potential resource in a welfare state model in which Arbeidslinjen, the focus in social assistance on reducing dependency on the welfare state through the work approach, has become a central feature: it dictates that in order to maintain a high level of welfare spending, people must engage in productive work (Brochmann, 2016). There is a presump- 
tion that a universal, "generous" welfare state rests on a well-functioning and strongly regulated labor market, and that this is not sustainable if some people or groups are not participating in the labor market (Bendixsen et al., 2018). Being a taxpayer becomes morally important in a context in which working citizens are thought to pay for a generous social and health benefits system (Bendixsen, 2017). Yet, by making it almost impossible to work, asylum seekers have a slim chance to position their group as contributors to the welfare state through paying taxes with consequences on how they can promote deservingness to rights. Instead, making it illegal to work feeds into the description of irregular migrants as a source of social problems and expensive welfare. Categorical inequalities linked to degrees of (un)deservingness (re)produce and confirm the process of Othering. Othering "defines and secures one's own identity by distancing and stigmatizing an(other). [The] purpose is to reinforce notions of our own 'normality', and to set up the difference of others as a point of deviance" (Grove \& Zwi, 2006, p. 1933). In this process, the Other is marginalized and frequently dealt with through services and assistance that are set up and defined by a humanitarian logic. In the case of refugees and migrants, these "Others" are sometimes viewed as a threat to the citizen population, i.e., the lack of identity documentation is viewed as a danger to national security, while their rights under the Act on Infectious Diseases (1994) can portray migrants as potential contaminants of public health.

Second, humanitarian exceptionalism becomes an instrument through which the welfare state can both confirm its efforts to manage and control migration and retain a humanitarian face. Irregular migrants receive care in a different logic than the welfare state's frame of solidarity, equality, and universality, namely through humanitarian exceptionalism. While excluding certain categories of people from welfare services, and thus the basic needs of the human body, the Norwegian welfare state accepts the existence of exceptional services that are legitimized and presented as humanitarian services, such as the health care center for paperless in Oslo. Such humanitarian exceptionalism (Fassin, 2012; Ticktin, 2011) characterizes how European welfare states deal with their irregular migration population today. Humanitarian exceptionalism is based on centering some human beings as victims, non-agentive and apolitical, who should be saved by a caring state, but who are offered only limited access to care. Charity and compassion for the suffering body are key elements of humanitarian governments of how irregular migrants are governed by a politics of control and politics of pity (Fassin, 2012). It produces and affirms irregular migrants as an "unwanted" population that is administrated through exceptional charity and care instead of through social rights.

By tolerating and in some cases providing basic services to irregular migrants in a different way than its citizens, the state can alleviate suffering through which it saves its image as a humanitarian power while uphold- ing the idea that deservingness, inclusion, and solidarity should be grounded on citizenship. The discourse of humanitarianism facilitates that the welfare state continues its limited assistance to "illegal residents" while continuing to portray an image of a just and caring state that will not let "anyone starve" on its streets. This is also, I suggest, the part of the reason why the state tolerates, and sometimes finances, parallel structures: their existence makes it possible for the state to continue withdrawing welfare rights from this population without attracting critique against its moral qualities. Simultaneously, through the dispersal of rights, the government confirms the narrative both to citizens who are concerned about "too much migration" and to prospective migrants that Norway is "hard on migration".

Third, these differentiations illustrate how migration management works through welfare regulations and its norms of deservingness. The welfare state has always included mechanisms for excluding certain people and evaluating who should have access to what (Ryymin \& Ludvigsen, 2013). Yet, in the case of irregular migrants, welfare rights become part of the border regime. The increased differentiation of residence permits systems that limit and prolong migrants' access to rights is both a part and a continuation of the physical border inside the nation-state (Rigo, 2005). Welfare state borders work through their differentiation of people within the territorial space by constructing different legal statuses with different sets of rights (Vuolajärvi, 2018). The borders are produced by the welfare state's differentiating function concerning rights, as well as the residence permit and visa system. Regulation of rights also produces social and symbolic boundaries between people who physically reside in Norway. Providing a limited right of access to health care to people without legal residence is part of the government's effort to appear "tough on migration", as a sanctioning tool for those irregular migrants who have a "duty to return" (Bendixsen, 2017), and to prevent health care migration in which migrants would come to Norway in order to receive free health care. It generates a differentiated and hierarchical fragmentation of legal subjectivities living in the same territory. It also contributes to a "(re)assertion of a national logic of territorialized prioritisation and concern" (Darling, 2010, p. 134) in the nation's work to define who has the right to belong.

\section{Conclusion}

The regulation of rights and access to welfare services is one way through which the welfare state deals with irregular migration and pursues its "people production". This article has investigated how the politics of differentiation works by examining the regulation of the right to work, health care and economic benefits. These aspects touch the core of being human. The different statuses and the differential rights linked to these statuses produce different forms of vulnerabilities, precariousness, and representations of the (irregular) migrant. 
This article has shown how the dispersal of rights has increasingly become part of structural differentiation and a part of the proliferation of borders. The regulation of the categories of people that have access to the $\operatorname{good}(\mathrm{s})$ of the welfare state simultaneously produces ideas of deservingness and inclusion/exclusion and puts weight on the welfare state-migration management nexus. By simultaneously introducing a humanitarian aspect, the government can avoid chaos, vociferous protests against how they treat irregular migrants, as well as keeping up the image of a caring welfare state and a humanitarian superpower. Humanitarianism becomes a way of making policies and the differentiating of rights more acceptable for citizens who are concerned with how refugees and migrants are treated. By providing some economic means to irregular migrants living in reception centers, the state can also have a better overview of who is in the country "illegally". This is useful in order to facilitate deportation.

Despite the fact that this discussion is mainly based in Norway, the conclusions reflect the broader direction of how regulation and welfare rights are used by EU member states. All European countries have a residence permit system by which applicants are differentiated, some of which are standardized according to the Schengen agreement. The production of differentiation in the legal statuses of non-citizens and the differentiation of rights are important in the proliferation of borders in Europe. The form and shape of the consequent hierarchy of belonging, humanitarian exceptionalism, and the welfare rights-migration nexus that are proliferated in the various European nation-states need, however, to be further explored and compared.

\section{Acknowledgments}

This research was supported by the University of Bergen (Norway) as part of the project Denaturalizing Difference: Challenging the Production of Global Social Inequality (DENAT), at the Department of Social Anthropology. The author would like to thank the anonymous reviewers for their valuable comments.

\section{Conflict of Interests}

The author declares no conflict of interests.

\section{References}

Abrams, P. (1988). Notes on the difficulty of studying the State. Journal of Historical Sociology, 1(1), 58-89.

Act on Infectious Diseases 1994 LOV-1994-08-05-55. Retrieved from lovdata.no/dokument/NL/lov/1994-0805-55 (Norway)

Agamben, G. (1998). Homo sacer: Sovereign power and bare life. Stanford, CA: Stanford University Press.

Anderson, B. (2013). Us \& them? The dangerous politics of immigration control. Oxford: Oxford University
Press.

Appadurai, A. (1996). Modernity at large: Cultural dimensions of globalization. Minneapolis, MN: University of Minnesota Press.

Balibar, E. (2002). Politics and the other scene. London: Verso.

Bendixsen, S. (2017). Voice matters: Calling for victimhood, shared humanity and citizenry of irregular migrants in Norway. In R. G. Gonzales \& N. Sigona (Eds.), Within and beyond citizenship: Borders, membership and belonging (pp. 185-207). London: Routledge.

Bendixsen, S. (2018). The politicized biology of irregular migrants: Micropractices of control, tactics of everyday life and access to health care. Nordic Journal of Migration Research, 8(4).

Bendixsen, S., Bringslid, M. B., \& Vike, H. (2018). Introduction: Egalitarianism in a Scandinavian context. In S. Bendixsen, M. B. Bringslid, \& H. Vike (Eds.), Egalitarianism in Scandinavia: Historical and contemporary approaches (pp. 1-44). London: Palgrave Macmillan.

Bigo, D. (2002). Security and immigration: Toward a critique of the governmentality of unease. Alternatives, 27(1), 63-92.

Bommes, M. (1999). Migration und nationaler Wohlfahrtsstaat. Ein differenzierungstheoretischer Entwurf. Wiesbaden: Westdeutscher Verlag.

Bommes, M., \& Thränhardt, D. (2010). Introduction: National paradigms of migration research. In D. Thränhardt \& M. Bommes (Eds.), National paradigms of migration research (pp. 9-38). Göttingen: V\&R Unipress.

Brochmann, G. (2016). Innvandring til Skandinavia. Velferdsstater i pluralismens tid. In I. Frønes \& L. Kjølsrød (Eds.), Det norske samfunn, bind 1 (pp. 130-155). Oslo: Gyldendal Akademisk.

Caudra, C. B., \& Staaf, A. (2014). Public social services' encounters with irregular migrants in Sweden: Amid values of social work and control of migration. European Journal of Social Work, 17(1), 88-103.

Chauvin, S., \& Garcés-Mascareñas, B. (2014). Becoming less illegal: Deservingness frames and undocumented migrant incorporation. Sociology Compass, 8(4), 422-432.

Cox, R. (2004). The path-dependency of an idea: Why Scandinavian welfare states remain distinct. Social Policy \& Administration, 38(2), 204-219.

Darling, J. (2010). A city of sanctuary: The relational re-imagining of Sheffield's asylum politics. Transactions of the Institute of British Geographers, 35(1), 125-140.

De Genova, N. (2002). Migrant 'illegality' and deportability in everyday life. Annual Review of Anthropology, 31(October), 419-447.

Fassin, D. (2012). Humanitarian reason: A moral history of the present times. Berkley, CA: University of California Press.

Fuglerud, $\varnothing$. (2005). Inside out: The reorganisation of national identity. In T. B. Hansen \& F. Stepputat (Eds.), 
Sovereign bodies: Citizens, migrants, and states in the postcolonial world (pp. 291-311). Princeton, NJ: Princeton University Press.

Guiraudon, V., \& Lahav, G. (2000). Comparative perspectives on border control: Away from the border and outside the state. In P. Andreas \& T. Snyder (Eds.), The wall around the West: State borders and immigration controls in North America and Europe (pp. 55-80). Lanham, MD: Rowman \& Littlefield.

Grove, N. J., \& Zwi, A. B. (2006). Our health and theirs: Forced migration, othering, and public health. Social Science \& Medicine, 62(8), 1931-1942.

Health and Care Services Act 2011 LOV-2018-06-2276. Retrieved from lovdata.no/dokument/NL/lov (Norway)

Isin, E. (2002). Being political. Genealogies of citizenship. Minneapolis, MN: University of Minnesota Press.

Jöhncke, S. (2007). Velfærdsstaten som integrationsprojekt. In K. F. Olwig \& K. Pærregaard (Eds.), Integration: Antropologiske perspektiver (pp. 37-62). København: Museum Tusculanum.

Justis-og politidepartementet. (2010). Norsk flyktningog migrasjonspolitikk i et europeisk perspektiv (Meld. St. 9, 2009-2010). Retrieved from www.regjeringen. no/no/dokumenter/Meld-St-9-2009-2010/id597820

Justis-og beredskapsdepartementet. (2016). Tildelingbrev for Utlendingsdirektoratet 2016 (Politidirektoratet Report). Retrieved from https://www. regjeringen.no/contentassets/23751a30c2a24f23ac 8f646973dc9bf4/2013/tildelingbrev-2013_pod.pdf

Karlsen, M. (2015). Precarious inclusion: Irregular migration, practices of care, and state b/ordering in Norway (Unpublished Doctoral dissertation). University of Bergen, Bergen, Norway.

Kildal, N., \& Kuhnle, S. (2005). The Nordic welfare model and the idea of universalism. In N. Kildal \& S. Kuhnle (Eds.), Normative foundations of the welfare state: The Nordic experience (pp. 13-33). London: Routledge.

Kjærre, H. (2015). Kontrollvelferd i det norske mottakssystemet: Mottakstilværelsen og livet utenfor. In S. Bendixsen, C. Jacobsen, \& K. H. Søvig (Eds.), Eksepsjonell velferd? Irregulære migranter i det norske velferdssamfunnet (pp. 203-222). Oslo: Gyldendal.

Kongeriket Norges. (2018). Kongeriket Norges Grunnlov [The Constitution of the Kingdom of Norway] (LOV1814-05-17). Norway.

Langset, K. G. (2011). Stiller urimelige og uetiske krav til helsepersonell. Aftenposten. Retrieved from www.aftenposten.no

Lavenex, S. (2006). Shifting up and out: The foreign policy of European immigration control. West European Politics, 29(2), 329-350.

Mezzadra, S., \& Neilson, B. (2013). Border as method or, the multiplication of labor. Durham: Duke University Press.

NTB. (2010). Frp vil forby legehjelp til ulovlige innvandrere. Bergens Tidende. Retrieved from www.bt.no
Nuland, B. R. (2007). Ansikt til ansikt med fattigdommen. Frivillige organisasjoners hjelpetiltak overfor fattige (Report 2007:18). Oslo: Fafo. Retrieved from www. fafo.no/index.php/zoo-publikasjoner/fafo-rapporter/ item/ansikt-til-ansikt-med-fattigdommen

Oslo Economics. (2014). Evaluering av ordninger for frivillig retur. Utarbeidet for Justis- og Beredskapsdepartementet (Report 27). Oslo: Oslo Economics.

Papadopoulos, D., \& Tsianos, V. S. (2013). After citizenship: Autonomy of migration, organisational ontology and mobile commons. Citizenship Studies, 17(2), 178-196.

Rigo, E. (2005). Citizenship at Europe's borders: Some reflections on the post-colonial condition of Europe in the context of EU enlargement. Citizenship Studies, 9(1), 3-22.

Roseberry, W. (1994). Hegemony and the language of contention. In G. Joseph \& D. Nugent (Eds.), Everyday forms of state formation (pp. 355-366). Durham: Duke University Press.

Rumford, C. (2010). Global borders. Environment and Planning D: Society and Space, 28(6), 951-956.

Ryymin, T., \& Ludvigsen, K. (2013). From equality to equivalence? Norwegian health policies towards immigrants and the Sámi, 1970-2009. Nordic Journal of Migration Research, 3(1), 10-18.

Seeberg, M. L. (2017). Alt er relativt: ytelser til barnefamilier i norske asylmottak, 1989-2017. Tidsskrift for velferdsforskning, 4(20), 268-285.

Sivesind, K. H., Lorentzen, H., Selle, P., \& Wollebæk, D. (2002). The voluntary sector in Norway: Composition, changes, and causes (Report 2). Oslo: Institutt for samfunnsforskning.

Skey, M. (2013). Why do nations matter? The struggle for belonging and security in an uncertain world. British Journal of Sociology, 64(1), 81-98.

Prime Minister's Office., \& Ministry of Justice and Emergency Affairs. (2016) Regjeringen: Nødvendige innstramninger (Press realease). Retrieved from www.regjeringen.no/no/aktuelt/ny-side/id2481689

Soguk, N. (1999). States and strangers: Refugees and displacements of statecraft. Minneapolis, MN: University of Minnesota Press.

Søvig, K. H. (2011). Provision of health services to irregular migrants with a special focus on children. European Journal of Health Law, 18(1), 43-54.

Ticktin, M. (2006). Where ethics and politics meet. American Ethnologist, 33(1), 33-49.

Ticktin, M. (2011). Casualties of care. Immigration and politics of humanitarianism in France. Berkeley, CA: University of California Press.

Utlendingsdirektoratet. (2018). Rutiner og satser for $\varnothing$ konomiske ytelser til beboere i statlig mottak, regulerte satser 2018. The Norwegian Directorate of Immigration. Retrieved from www.udiregelverk.no

Valenta, M., \& Thorshaug, K. (2011). Asylsøkeres rett til å ta arbeid. Evaluering av konsekvenser av innstramminger i dokumentasjonskravet. Trondheim: NTNU 
Samfunnsforskning.

Van der Leun, J. (2006). Excluding illegal migrants in the Netherlands: between national policies and local implementation. West European Politics, 29(2), 310-326.
Vike, H. (2004). Velferd uten grenser: Den norske velferdsstaten ved veiskillet. Oslo: Akribe.

Vuolajärvi, N. (2018). Precarious intimacies: Europeanised border regime and migrant sex work. Journal of Ethnic and Migration Studies, 1-18.

\section{About the Author}

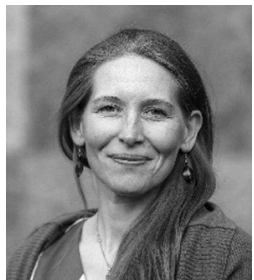

Synnøve Bendixsen is a Postdoctoral Fellow at the Department of Social Anthropology, University of Bergen (Norway), as part of the ISP-RCN project Denaturalizing Difference: Challenging the Production of Global Social Inequality (DENAT). She received her PhD. in Social Anthropology from Humboldt University (Germany) and École des Hautes Études en Sciences Sociales (France), a double diploma. Her research interests include migration, religiosity, Muslim youth, Islam, irregular migrants, political mobilization, and border formations. 